\title{
Construction of Brand Core Value and Brand Concept of High-quality Private Education
}

\author{
Biyue Long \\ Design Department \\ School of Information Science and Technology \\ Guilin University of Electronic Technology \\ Guilin, China
}

\begin{abstract}
With the perfection of China's private education policies and regulations, our private education greets an opportunity of development. Under fierce market competition, private education needs to run with the brand strategy and excellent education resources to acquire long development. The brand strategy will facilitate private education to expand and develop superior resources. Private education should find their own brand core value and establish brand concept, so as to carry out different development strategies in fierce market competition and get recognition.
\end{abstract}

Keywords-private education; brand core value; brand concept; brand management

\section{INTRODUCTION}

With the development of market economy in China, educational concepts and thoughts have also undergone earthshaking changes. The education industry transforms from single public form into a diversified, comprehensive and independent form. With the perfection of a series laws and regulations, various private education institutions and schools spring up rapidly. A variety of economic forces and talents flow over into the new education system, which prospers this system.

Throughout market changes, the success of high-quality private education groups often owes to their advanced education management concepts. They have their own characteristics and establish a scientific brand management mode. These intangible assets have irreplaceable significance in the further development of private education.

\section{Shaping The BRAND CORE VALUE OF High-Quality PRIVATE EDUCATION}

In the era of brand competition, all private schools should seize the opportunity to actively plan. They can draw lessons from excellent enterprises about brand strategy planning, and meanwhile construct own brand core value and brand advantages according to their own characteristics in order to shape a brand and go the road of brand strategy. As the soul of private education brand, core value is the source of all brand assets. The core value of brand should be special and identifiable, and it can make people effectively distinguish it from competitors, strengthen consumers' brand memory,

Research orientation: product design, education and teaching management. cultivate brand association and realize brand loyalty.

\section{A. The Attribute of Core Value}

School is different from enterprise. Enterprise can possess many products and various marketing methods or many brand strategies. Therefore, the core value of brand can be different from core value of enterprise. School is a place to learn knowledge and culture, and to exchange ideas and cultivate talents. "It takes a hundred of years to bring up a generation of people" is a long education thought. We cannot change it casually in the period of "bring up a generation of people". So, it is ideal to keep the brand core value of school consistent with the core value of school in the construction of brand. The core value of brand surpasses the limitation of times, and guides the long development of school. For example, Peking University has a long history. In its development, the core value of the school is always consistent with the core value of its brand. The core concept of "absorbing everything and freedom of thought" is deep into hearts of people. And it helps us understand the core value of its school and the core value of its brand.

In the process of seeking the core value of the brand, many schools have a wrong understanding. Some school leaders replace the core value of brand with schooling philosophy, which has unconsciously narrowed the core value of brand. The core value of brand is inclusive, and it is the value orientation of schooling philosophy. It can guide various forms of education. Schooling philosophy is the real expression and the concrete practice of the brand core value of school in the education and teaching practice. The brand core value of "absorbing everything and freedom of thought" is also suitable for characteristic multi-education. Some schools take staged development goals as their brand core value, and thought it could reflect their schools' education characteristics. For example, some schools have rich resources of art education, so they are characterized by the cultivation of art students. In their publicity, they treat "to build art education brand and cultivate talents of art and morality" as their brand core value. They neglects that school brand is gradually precipitated along the construction and development of school, and it surpasses any characteristic education mode in any stages of development of school. Characteristic education can be a highlight. It maybe only fits to current society and current teaching environment. Some schools may have many specialities in the development, 
and current education characteristics may change with the changes of social demand. These are all unknown variables. So, the education characteristics of school should be the concrete era reflection of the brand core value of school. Staged development goal shouldn't split the historical inheritance of core value; otherwise it will reduce the grade of school culture.

The brand core value of school should be stable, inclusive and extensive. For example, the brand core value of Beijing Huiwen Middle School is "wisdom, kindness and braveness" which is handed down in its long development. It is originated from Zhong Yong. It says "love of learning is wise; be dear to others is kind; to know the shame is brave", which has the cultural deposits and is very practical in teaching and education. It is the brand core value of Huiwen School as well as the motto of their teachers, staff and students. It can stimulate generations of Huiwen people to devote to work, cultivate their moral character and make progress constantly, so that the brand core value of this school is fully reflected.

\section{B. The Refining of Core Value}

In practice, the following points can be referred to refining the brand core value. First, adopt measures to local conditions, including local geographical, natural and humanistic characteristics. Many schools have their special geographical locations, such as the ethnic minority areas, old revolutionary base areas and the humanistic scenic spots. They all have a profound cultural deposit and spiritual style. To use or interpret the culture of these areas is geographically conducive to improving brand connotation and highlighting the special value of brand. Second, cite the traditional cultures and take traditional cultures as leader. Chinese traditional culture contains profound educational and philosophical thoughts which can provide abundant resources for the refining of core value. Many schools refined their brand core value form traditional cultures. Just like above-mentioned Huiwen School, their brand core value of "wisdom, kindness and braveness" sources from Zhong Yong. For another example, the core value of Tsinghua University, as we all know, is "ceaseless self-improvement and social commitment" which sources from Yi Jing. It is the paraphrase about gentleman in Qian Gua and Kun Gua. Third, excavate historical characteristics and carry forward historical heritage. The core values of many schools source from deep understanding on their historical development reasons. For example, the prestigious Nanjing University laid down their school motto of "honesty, majesty, self-improvement and diligence" as their brand core value in its centennial anniversary which contains the essence of mottos in four historical stages. It is a heritage and respect to the historical development of school. Nanjing University was first called as Liangjiang Normal University. At that time, the supervisors advocated simplicity and diligence. In the stage of "Nangao", the motto is honesty. Later, it developed into "Southeast University". It advocated "three educations", discipline education, intellectual education and physical education. In the stage of "Centre University", they put forward the motto of "honesty and majesty". In its anniversary in 2002, the motto eventually was set as "honesty, majesty, self-improvement and diligence" to reflect the constant spirituality of the centennial prestigious university.
In addition, the core value of brand should be combined with a good object in the promotion and refection. And the motto is the best carrier of brand core value. The content of motto often involves education goal and content, scholarly pursuits and self-cultivation, ways of treating people and other programmatic items. The motto has the power of education and influencing people. Its artistic conception and doctrine could pervade the whole campus, and help build the spiritual atmosphere of the university. It can gather the strength of teachers, staff and students, and restrain their behaviors. In addition, it can appeal everyone to identify its core value, and make them yearning and respect.

According above discussions, the author summed up the key points to shape the brand core value, as shown in Figure 1:

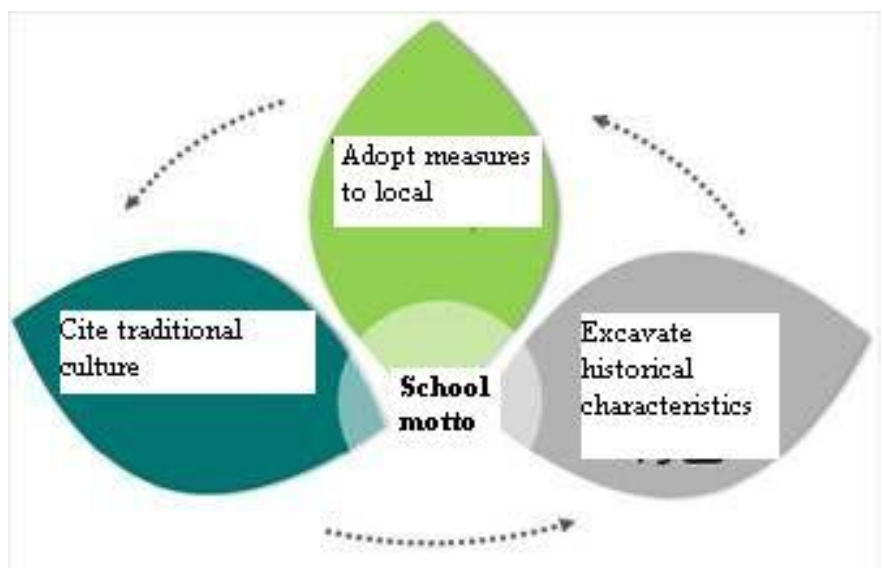

Fig. 1. Brand Core Value Shaping Structure

It could lay a solid foundation for the realization of brand strategy to shape the brand core value. The establishment of core value could support the perfection of brand concept and guide brand positioning. However, it is not enough to only have brand core value. The brand concept needs to be perfected based on the brand core value, for it can provide basis for brand image building and brand behavior construction.

\section{BRAND CONCEPT CONSTRUCTION}

School brand concept construction refers to school making rational thinking and understanding on how to construct the brand after determining to go the brand construction road. It forms a set of operating systems conducive to the development of school brand. It defines thoughts and ideas of the school brand design, and direct school brand behavior and brand image. Seen from its content, it mainly include brand positioning (what is school brand), brand development vision (what the brand will do), and brand management strategy (how to manage this brand).

First, determine the core value of the brand, and then make brand positioning according to the core value. Through survey and based on brand positioning, carry out design of brand development vision. Second, make brand management strategy. Organize experts to discuss, revise and perfect design program of school brand concept. At last, form the text result of brand 
concept - School Brand Concept Handbook. To sum up, the key points of the school brand concept design are summed up in the following figure:

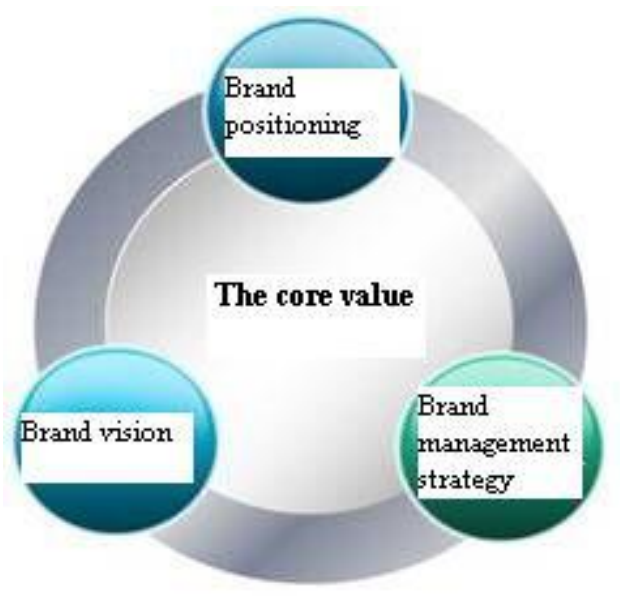

Fig. 2. Brand Concept Building Structure

According to the school brand concept design model, the paper discusses the brand concept design from three aspects:

\section{A. Brand Positioning Design}

Brand positioning design refers to the establishment of its development, distinct competitive advantages, receiver groups and social status of the school, so that social people can understand and identify the characteristics of the school from other schools. School brand positioning is a system, which includes the positioning of educational characteristics, grade, education and teaching quality, student source, students' development goals, brand image and school scale. From the above content, the school brand positioning system can be divided into four levels: to determine the nature of school brand, to determine the development direction of the brand, to determine its image and to determine its scale. The nature involves in characteristics positioning, quality positioning and student source positioning. The development direction of the school involves grade (international, domestic advanced, provincial key or country-level brand), education consumer groups and students' development goal. The image involves school image, brand image, teacher image and student image. The scale refers to the school scale, involving the number of students, the number of teachers, hardware facilities and equipment, etc. Through the above discussion, the school brand positioning system is a rich, three-dimensional system. The visual school brand positioning system structure is summed up as shown in Figure 3:

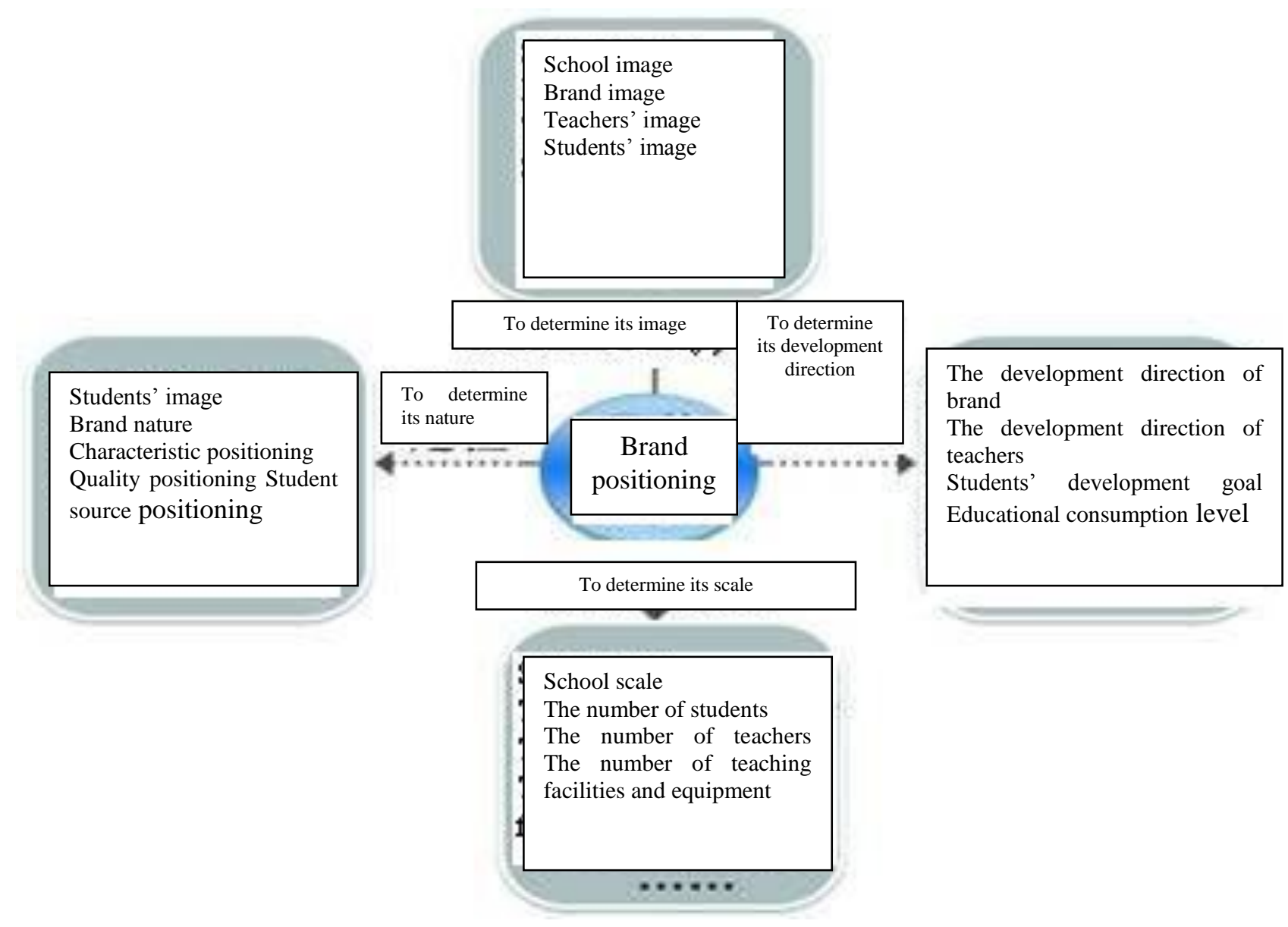

Fig. 3. Brand Positioning Structure 
In addition, the school brand development may changes in different periods. The development of school brand can be divided into the recent term, the medium term and the long term, as shown in Figure 4:

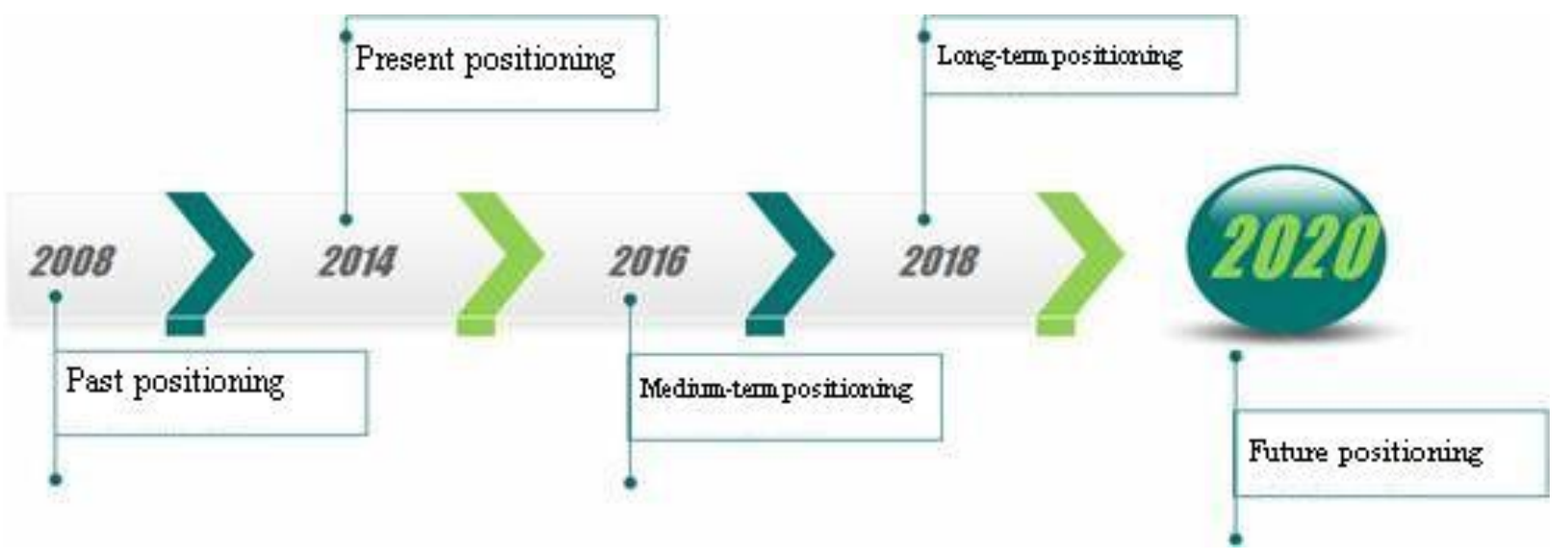

Fig. 4. Brand Building Time Plan

\section{B. Brand Vision Design}

Brand vision design is the programmatic blueprint of the future vision of school and long-term strategic objectives. It is based on brand positioning and its realistic development status. Schools set vision according to their brand concepts, so that the faculty and students have a goal to fight. It is the specific appeal of a school which spreads over all links of school and connects all activities and work of school together, and then endows school with a unique temperament. Schools should make brand vision design according to scientific and detailed analysis, rather than imagine without foundation. Brand vision design also should get high recognition of the faculty and students of the school and the society, and accurately outline the value orientation of the brand and social status of the brand. The description of school vision should be simple and rational, with cultural connotation and appeal. For example, ZoupingCounty Experimental Primary School in Anhui put forward the brand vision of "advocating traditional culture and devoting to the happiness of students and the faculty". Some schools, with rich resources and advantages, have lofty visions. For example, The High School Affiliated to Renmin University of China put forward the vision of "domestic advanced and international first-class elite school". It is worth mentioning that the vision of the design is the expression of school teachers and students' hopes, so it should be cohesive and driving, reflecting the strength and confidence of the school. Once it is established, the faculty of the school should treat it as long-term fighting goal, and they should realize it with enthusiasm and efforts. The brand vision design structure is as shown in Figure 5:

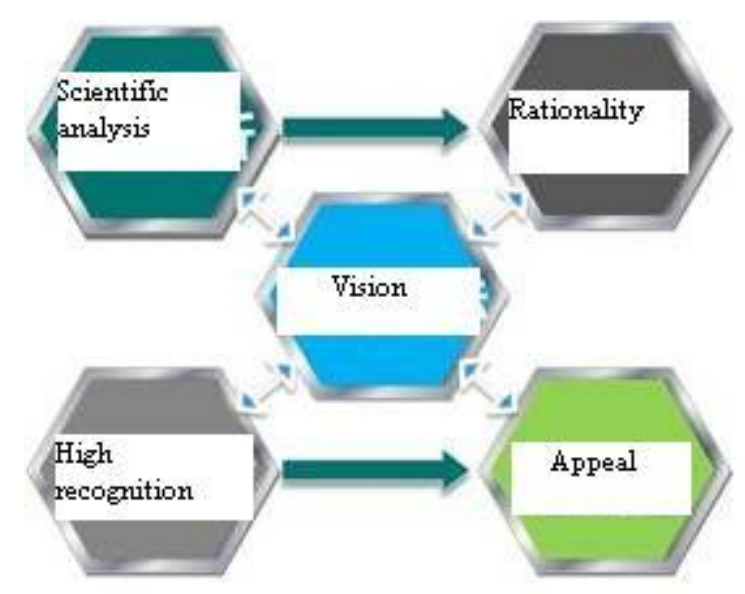

Fig. 5. Brand Vision Design Structure

\section{BRAND MANAGEMENT PATTERN}

Different enterprises have different attributes which leads to different brand management strategies. Different enterprises have different products, as well as their markets, management patterns, cultural connotations, brand concepts, leading and management style, etc. These differences result that enterprises should deal with different aspects in selection of brand strategy.

The school brand management strategy is targeted by the brand development vision. It takes the core value as mission, and relies on relevant theories, technologies, strategies and methods. It forms the implementation steps and process of brand construction in a macro aspect. The brand management strategy of school needs to consider the following points:

\section{A. To Establish the Schooling Purpose and School Structure}

Branding decision clearly defines the attribute of the brand. Before the construction of the brand, enterprise should determine to select the brand of manufacturer or the brand of 
dealer, to establish their own brand or join other brands. Once it is determined, the nature of the brand is established. Some forward-looking private institutions have established their own brands, such as Aptech and New Oriental. They own good reputations in the market. With changeable market environment, schools should determine whether to run own brand or to join other brands. Different brand management strategy indicates different management road and fate. Therefore, it is particularly important to identify market positioning, and do sustainable brand planning well. To select brand model is to determine the structure of the brand. It determines to select single integrated brand or diversified multi-brand, to use co-branding or dominant-secondary brand. There is no good brand model or bad brand model, but it has certain profession serviceability and timeliness, such as "moral education brand", "teaching brand" and "management brand". The private institutions and schools need to define their receiver objects in the construction.

\section{B. To Establish Brand Connotation and Build Brand Image}

The focus of this aspect is the brand identity which is the main part of brand strategy. Its main task is to establish the connotation of the brand, and build a brand image that consumers identify. It can standardize internal and external connotations of ideas, behaviors and appearance of the brand from three aspects, concept identity, behavior identity and symbol identity. It also includes core identity, taking the core value of brand as center, and basic identity, composed by brand commitment and brand personality. In the private education industry, most of schools and institutions have weak brand image awareness. They have names but no clear identity and education concept, and lack standardized management system. The best way to adapt to the market development is to design a set of personalized image identity system with visual communication principle that includes education concept and spiritual culture, and is identified by parents and students. It is composed of mind identity (MI), behavior identity (BI) and visual identity (VI), which helps to establish the image, create a famous brand, and improve brand positioning. In the following chapters, the author will focus on the discussion on brand image strategy of private education.

\section{To Define Management Planning and Establish Behavior Culture System}

Brand management planning can helps organize sectors and establish management system in the construction of image. It sets up vision for the development of image based on the above planning, and defines goals and assessment indicators in each development stage of the brand. It says "it takes a hundred years to bring up a generation of people" in the education industry. We should lay emphasis on deposit and culture excavation, construction of style and characteristics in order to develop education brand. The paper will discuss the establishment of brand behavior of private education in detail in later chapters.

\section{To Set the Future Development Goal and Develop the Brand Extension Planning}

The setting of future development goal of the brand is to define the existing brand value, future prospects and belief standards. Brand development goals should define key points for each stage of brand construction, so that there are hopes for the today, tomorrow and future of brand, and impetus to achieve the brand concept.

Those who do not plan for the future will find trouble at their door step. To make a good strategy is the basic condition to develop a brand. To develop a brand extension planning is a good way to define the future development field of a brand. Therefore, it can reduce risk, avoid brand dilution, maximize the brand value and make the brand touch people's heart to define the future fields and industry development and extension of the brand.

\section{CONCLUSION}

On the road of developing high-quality brand strategy, the accurate positioning of brand core value and characteristic schooling philosophy affects the long-term development of private education, because it can strengthen the cohesion and centripetal force of private schools. Only by advocating unique values and sense of responsibility, closely linking to the society and forming a concept of identity, can private education establish their brand image, affect the public and get the recognition of the society.

\section{REFERENCES}

[1] Wei Pizhi. Development and Problems of Contemporary Chinese Private Education. Song of the Yellow River. 2013 (20): 43-46.

[2] Yan Deming. Introduction to School Brand. Guilin: Guangxi Normal University Press, 2008.

[3] Weng Xiangdong. Local Brand Strategy. Nanjing: Nanjing University Press, 2008.

[4] Tian Hanzu. School Brand Management Principles and Strategies. Beijing: Capital Normal University Press, 2009.

[5] Tao Xiping \& Wang Zuoshu. Chinese Private Education. Beijing: Education Science Press, 2010

[6] Lan Xiaohua. Brand Management. Beijing: Peking University Press, 2011 